\title{
IAMJ
}

INTERNATIONAL

AYURVEDIC

MEDICAL JOURNAL

\section{A CLINICAL REVIEW OF TILA TAIL MATRA BASTI IN THE MANAGEMENT OF GRIDHRASI W.S.R TO SCIATICA}

\author{
C.S. Tanmane ${ }^{1}$, S. Wagh $^{2}$, T. P. Petkar ${ }^{3}$ \\ Prof and H.O.D Kayachikitsa Dept ${ }^{1}$, Prof and H.O.D Roganidan Dept ${ }^{2}$, P.G Scholar Kayachikitsa Dept ${ }^{3}$ \\ B.M.A.M Nandanwan, Nagpur, Maharashtra, India
}

Corresponding Author:tanushreepetkar24082408@gmail.com

https://doi.org/10.46607/iamj4609072021

(Published Online: July 2021)

Open Access

(C) International Ayurvedic Medical Journal, India 2021

Article Received:22/06//2021 - Peer Reviewed:24/06/2021 - Accepted for Publication:25/06/2021

\section{Check for updates}

\begin{abstract}
Gridhrasi(Sciatica) is Vataj Nanatmajvyadhi, having shifting pain in lower limb radiating from Sphik, Prushtha and affecting Uru, Janu, Jangha and Pada in order. Gridhrasi is of two types 1) Vataj: characterized by severe pain 2) Vata-Kaphaja: has symptoms Tandra, Gaurav and Aruchi. Basti is most common among Panchakarma due to its multiple effects. Pitta and Kapha are dependent on Vata as it governs their functions. Basti is not only best for Vata disorders, but also equally effective in correcting the morbid Pitta, Kapha and Vata. Charaka Acharya has considered Basti therapy as half of the treatment of all disease. Matrabasti is subtype of Anuvasan Basti. It is administered in very small amount and hence is very convenient in present day life. All acharya has explained about Matrabasti and considered safe and useful in many conditions where other varieties of Basti are contraindicated. It is specially used to treat various Vataja disorders. Signs and symptoms of Ghridrasi are relived when treated with Tila Tail Matra Basti.
\end{abstract}

Keyword: Gridhrasi, Matrabasti, Sciatica, Nanatmaj Vyadhi, Anuvasanbasti, Vataja disorders, Tila Tail. 


\section{INTRODUCTION}

Gridhrasi is the most obstinate and Prominent one amongst the 80 types of Nanatmaja disorders ${ }^{[1]}$. All most all signs and symptoms of Gridhrasi resemble with the condition of sciatica, As described by modern texts. Sciatic nerve is formed from the L4 to S3 segments of Sacral plexus. Sciatic neuralgia is defined as pain in the distribution of Sciatic nerve due to pathology of nerve itself (ex herniation of one or more lumbar intervertebral discs, Spinal tumors and infections that may compress sciatic nerve) ${ }^{[2]}$ In case of Gridhrasi specific Nidana has not been mentioned. Since Gridhrasi is considered as Nanatmaja Vata diseases, so causative factors producing Vatavyadhis are considered as nidana of Gridhrasi. Factors that provoke Vatadosha are causative factors for Vata diseases. In addition to this, in Charakasmahita, Astangasangraha and Ashtanga hridaya, the specific causes of vatavyadhi i.e. Dhatukshaya and Avarana have been also mentioned $^{[3]}$ As Gridhrasi is one of the 80 types of Vatavyadhi, the minor symptoms present before the manifestations of the disease may be taken as the purvarupa $^{[4]}$ Ruk (pain), Toda (pricking pain), Stambha (stiffness), Spandana (Twiching). Sakthikshepananigrahanti: Shushruta has mentioned this symptoms Dalhana says that Kandara that forbids the movement of the limb is called Gridhrasi. This is an additional manifestation of limited mobility of the affected leg. The word Kshepa means Prasarana are the extension in which patient has to keep the leg in flexed position which increases the pain. Vagabhata says this Lakshana in a different way by using the word "Utshepana: in the place of "Kshepa" which means that the patient is unable to lift the leg. Arunadutta very clearly defines it by using the word "pada udharane Ashakti" it means the patient is unable to elevate or lift the leg. Dehasyapipravakrata: Madhava described the symptom on account of pain that means the lateral and forward bending of body. The patient of Gridhrasi keeps the leg in flexed position and tries to walk without much extending the leg. Thus, the whole body is tilted on the affected side and gives him a bending posture or limping. The gait is also typical.

Rupa of Vatakaphaja Gridhrasi: Tandra (Lethargy), Gaurava (Feeling of heaviness of the body), Arochaka (Anorexia), Agnimandhya, Mukhapraseka, Bhaktadwesha (Lack of desire to eat), Staimitya.

\section{Samprapti Ghataka: ${ }^{[5]}$}

- Nidana: vataprakopakahar vihara

- Dosha: vata (Vyana and Apana),Kapha

- Dushya: Rasa, Rakta, Asthi, Majja, Sira, Kanadar, Snayu.

- Agni: Jatharagni and dhatawagni

- Ama: Jatharagnijanya and dhatawagnijanya

- Udbhavasthan: Pakawashaya

- Sancharasthan: Rasayanies

- Adhisthana: Pristha, Kati, Sphik

- Strotas: Rasa, Rakta, mansa, medo, Asthi and Majjavahastrotas

- Vyakta: Adhosakthi-uru, jane jagha and pada.

- Swabhava: Aashukari / Chirkari

Sadhyasadhyatva: ${ }^{[6]}$

Naveen- Krichsadhya. Asadhya- Gridhrasi is avatavyadhi and all the Vatavyadhi becomes Asadhya (incurable) or Durroopakrama (complicated) if neglected after a certain period.

Pathya: ${ }^{[7]}$ Raktashali, Purana shashtikashali, Kulatha, Maasha, Godhum, navintila, Lavana, Dugdha, Ghrita, Dadhi, Matsyandika, Dadhikurchika, Patola, Shigru, Vartaka, Lashuna, tambula, jalkrida, samvaha, parisheka etc.

Apathya: Chanaka, Shyamak, Nivarkangu, Mudga, rajamashak, Kattilaka, Bimbi, Kasheruka, Tadag, Viruddha annaDravyas having Kashaya Katu, Tikta Rasa, Chinta, Ratrijagaran, Vegavidharana, Shrama, Nidradhikya etc.

\section{Management:}

All acharyas have appreciated basti is unique form of treatment modality. It is incomparable elimination therapy than the others because; it expels the vitiated Doshas rapidly as well as it nourishes the body. Basti has its effect in colon, through its power it pulls all impurities out from head to toe, just as the sun that stands high in the sky dries up all rivulets. Matrabasti 
contains individually prescribed oils that target specific situations, while at the same time it nourishes the physiology. The Anuvasanbasti assure that the toxins that have been loosened by various oil massages make their way out of the body ${ }^{[8]}$.

Vagbhatta says the Virya of Basti is conveyed to Apana and then to Samanavata, which may regulate the function of Agni. It then goes to Udana, Vyana and Prana, thus providing its efficacy all over the body. At the same time Basti by pacifying Vata, restores the disturbed Kapha and Pitta at their original seat and thus helps in breaking the pathogenesis. Thus, according to Ayurveda, the Veerya (active principle) of the Oil used in the Basti get absorbed and then through the general circulation, reaches at the site of the lesion and relieves the disease. ${ }^{[9]}$

Pharmacokinetics studies have also proved that drug administrated via rectum can achieve higher blood levels of the drug than oral route due to partial avoidance of hepatic first -pass metabolism. The rectum has a rich blood and lymph supply, and drugs can cross the rectal mucosa as they can other lipid membranes thus un- ionized, and lipid soluble substances are readily absorbed from the rectum. The portion absorbed from the upper rectal mucus is carried by the superior hemorrhoidal vein into the portal circulation, whereas that absorbed from the lower rectum enters directly into the systemic circulation via the middle and inferior hemorrhoidal veins thus an administration of Anuvasana Basti has faster absorption and provides quicker result. The rectal wall contains neuroreceptors and pressure receptors which are stimulated by various Basti. Stimulation results in increase in conduction of sodium ions. The inward rush of sodium ions through the membrane of the unmyelinated terminal is responsible for generating the action potential. Generally, the action potential is initiated by increase in permeability of sodium ions. The Basti immediately after entering Pakwashaya (intestine), strike at the very root of vitiated vata. By virtue of their permeability the Basti may increase the normal bacteria flora of the colon and they're by modulate the rate of endogenous synthesis of vitamin B1 and B12 as well as Vitamin K. ${ }^{[10]}$

\section{Case Report:}

\section{Chief complaints with duration}

1. pain in lower back which is radiating to posterior aspect of left leg for 1 month. Pain has increased for 1 week.

2. Dragging type of pain, difficulty in sitting, standing and unable to walk properly for 1 week.

3. Pulling type of pain in left calf and thigh region

4. Associated with patient also c/o Tandra and Gauravta for 1 week

\section{History of personal illness}

A male patient aged 40 years presented with the complaints of back pain and then gradually radiates to posterior aspect of Uru, Janu, Jangha and pada of left side for 1 month. Also complaining of dragging type of pain, difficulty in sitting, standing for 1 week, associated with patient also complaining of Tandra and gauravta for 1 week. Hence patient consulted a local doctor and was advised some oral medication and rest. but patient was not relieved and from 1 week there was increased in the severity of symptoms. H/O heavy weightlifting hence patient came to our hospital for further management.

\section{Purvavyadhivrittantant:}

No/H/O- HTN/ DM/ T.B/ASTHAMA/ other systemic illness.

No surgical history

Family history: Nothing significant.

\section{Personal history:}

- Ahar: Mixed diet. Morning at 7 am drinks 3 glass of shitta Ambupana, nonveg once a week

- Vihar: shopkeeper, he sits in the same position for almost 5-9hrs since $30 \mathrm{yrs}$, control his thirst and urge to micturate.

- Appetite: Decreased appetite but takes food regularly.

- Bowel: for 4 months hard, straining.

- Micturition: Normal

- Sleep: Disturbed since 3 yrs., Due to pain

- Habits: nil 


\section{Astastana Pariksha}

- Nadi-88/min

- Mala-Baddhata (constipated)

- Mutra-4-5 times a day, 1 time in the night

- Jiwha-Alpa-saam (coated)

- Shabda-Normal

- Sparsha-Slight tenderness present over the lumbar region

- Druk-Normal

- Akruti- lean built.

- B.P- $120 / 80 \mathrm{~mm} / \mathrm{hg}$

\section{Dashvidhapariksha}

1. Prakriti: Vata-Pitta

2. Vikriti:

- Hetu- Long hours of sitting, Lifting heavy weights, Vegadharana, Nidrahaani.

- Dosha-Vata

- Dooshya-Asthi, Sandhi, Mamsa

- Prakriti-Mridu

- Desha-Bhumi: Annupsadharana

Atura-Kati, Vamasakthi

- Kala-Ritu: Varsharitukriyakaala-Vyaktaavastha

- Bala-Rogi: Avara, Roga: Madhyama

3. Sara: Madhyama

4. Samhanana: Madhyama

5. Satva: Madhyama
6. Satmya:Madhyama

7. Ahara shakti: Abhyavaharana ShaktiMadhyama, Jarana Shakti-Madhyama

8. Vyayamashakti: Avara

9. Vayah: Madhyama

10. Pramana: Madhyama

Locomotor system:

- Gait: Limping with support

- Upper limb: Normal

- Lower limb: Stiffness in the calf and thigh region, Redness, weakness, swelling present. Local temp raised.

\section{Deformity- Absent}

- Examination of spine-

1. Inspection: No visible deformity

2. Palpation: Tenderness in L5 S1 S2

3. Movements: Cervical/Thorasic: NAD, Lumbar: Flexion Restricted, Lateral Flexion Lt- Not possible Rt- Restricted, Extension- Restricted

SLR test: positive at $45 \mathrm{degree}$ left leg.

Lasegues sign: Positive

Investigation

Hb- 13 gm\%, ESR-24mm/hr, RBS-109 mg/dl, Urine sugar: Absent, MRI- mild diffuse bulge at L4, L5 level

\section{Treatment protocol}

\begin{tabular}{|l|l|}
\hline Poorvakarma & $\begin{array}{l}\text { Deepana and Pachana } \\
\text { Patient is asked to evacuate bowel bladder, made to lie in the left lateral position with the Right leg } \\
\text { flexed. } \\
\text { Sarvang Abhyanga with Tilataila and Dashmoola Nadi Sweda }\end{array}$ \\
\hline Pradhanakarma & $\begin{array}{l}\text { The tip of the catheter is smeared with oil. The anal orifice is lubricated with oil. The catheter is then } \\
\text { introduced into the anal canal till 4-6 inches and TilaTaila Matrabasti is given by Tila Taila is pushed } \\
\text { into the Rectum, the catheter is gently pulled out. }\end{array}$ \\
\hline Panchakarma & $\begin{array}{l}\text { Sphikthadana is done. Patient is made to lie on supine position. Patient is made to rise the legs by Flexing } \\
\text { the hip 3-4 times. Patient is advised to take rest after Sukhspurvaka Pratyagamana of Basti } \\
\text { Sukhoshnajalasnana } \\
\text { Adviced to take Supachyalaghuahar }\end{array}$ \\
\hline
\end{tabular}

\section{Study Duration:}

- $1-7^{\text {th }}$ day:TilatailaMatrabastiis given

- 7 days followed by Parihara kala of 14 days.

- Follow up after 21 days.

\section{Observation and Result}

The result observed after the treatment, improvement in signs and symptoms of the patient. Relief was found in symptoms of back pain, numbness and 
tingling sensation. Gait has improved. The patient has

complete relief so she can sit comfortably.

Table 1: Showing effect of therapy on Subjective parameters.

\begin{tabular}{|l|l|l|l|}
\hline Subjective Parameters & Before Treatment & After Treatment & After Follow up \\
\hline Ruk & $\begin{array}{l}\text { Moderate painful walk with limping } \\
\text { without support }\end{array}$ & $\begin{array}{l}\text { Relief was found in back pain } \\
(70-80 \%)\end{array}$ & $\begin{array}{l}\text { Relief was found in } \\
\text { back pain }\end{array}$ \\
\hline Sthamba & $\begin{array}{l}\text { Mild stiffness }(1-10 \mathrm{~min})-\text { up to } \\
\text { 25\% impairment } \\
\text { Patient can perform daily work }\end{array}$ & $\begin{array}{l}\text { Relief was found in stiffness } \\
\text { Relief was found in } \\
\text { stiffness }\end{array}$ \\
\hline
\end{tabular}

Table 2: Showing effect of therapy on Objective Parameters.

\begin{tabular}{|l|l|l|l}
\hline $\begin{array}{l}\text { Objective } \\
\text { Parameters }\end{array}$ & $\begin{array}{l}\text { Before } \\
\text { Treatment }\end{array}$ & $\begin{array}{l}\text { After } \\
\text { Treatment }\end{array}$ & $\begin{array}{l}\text { After } \\
\text { Follow up }\end{array}$ \\
\hline SLR (Right leg) & 45 degrees with pain & 70 degrees without pain & 70 degrees without pain
\end{tabular}

\section{DISCUSSION}

Gridhrasi is such a disease having its origin in Pakwashaya (large intestine) and seat in Sphika and Kati i.e. Lumbat spine. Acharya Sushrutahas emphasized the involvement of Kandara (ligament) from Parshni (calcaneal bone) to Anguli (fingers) in producing the disease Gridrasi; he also added an important sign Saktthishepanigraha i.e., rest) The signs and symptoms of Gridhrasi can be correlated to sciatica of modern medicine. Sciatica is caused due to compression or irritation of sciatic nerve, the injury to sciatic nerve and its branches results in Sciatica. S.L.R test, it plays a major role in diagnosis of the disease and assessment of effect of therapy as an objective parameter. In Charaksamhita Bastikarma (Niruhu and Anuvasan), Siravedha and Agnikarma. ${ }^{[1]}$ Sushruta acharya has advised Siraveda at Janu after flexion. ${ }^{[12]}$ Astangasangraha and Astanga Hhridaya have also advised Siravedha four Angula above janu. Chakradutta has given the treatment of Ghridrasi in details. He has stressed that Basti should be administered after proper Agnidipan, Pachan and Urdhvasodhana. Also mentioned Siravedha four Angula below Indrabasti Marma, if not relived by this treatment, then Agnikarma at Kanishthika Anguli of pada has been suggested ${ }^{[13]}$. Yogratnakar has advised Siravedhain the area of four Angula around Basti and Mutreendriya, if this fails Agnikarma in the little finger of the leg is advised in the management of Gridhras ${ }^{[14]}$. So according to
Charaka acharya suggest that Anuvasana Basti therapy not only produced symptomatic relief but also control the disease process and may case long lasting effect ${ }^{[15]}$.

\section{CONCLUSION}

Basti is one of the most practiced therapeutic procedure that can be done on OPD basis. In Ayurveda Basti therapy is considered as Ardhachikitsa. Matrabasti is the type of Anuvasana Basti in which Sneha is administered in lowest dosage i.e., Quarter $\left(1 / 4^{\text {th }}\right)$ quantity of Sneha, this dose is equal to the dose of HrisvaSnehapan. It is indicated in people debilitated due to heavy work, Exercise, lifting heavy weight and in persons afflicted by disease due to Vata Dosha. It increases Bala, helps in easy and comfortable evacuation of Mala and pacifies Vata Dosha. Tila Tail is easily available and affordable, Tila Tail Matrabasti was given for seven days, and significant improvement was observed.

\section{REFERENCES}

1. Charaka Samhita (Agnivesh) vol. V, English translation by ram karansharmavaidya bhagwan dash, Published by Chaukhambakrishandas Academy, Gopal Mandir Lane, Varanasi, 2015. Page No. 35

2. Davidson's principles and practices of medicine, 17 th edition, edited by C.R. WEwards I.A.D. Bouchier, C. Haslett published by ELBS with Churchill livingstone in 1996 pno864. 
3. Charaka Samhita (Agnivesh) Part 1- charakachandrika Hindi Commentary by brhmanandtripathii, prabhakarjanardan deshpande, Published by Chaukhamba Bharti Academy, Gokul Bhawan, Gopal Mandi Lane, Varanasi, 2009. Page No. 391

4. Sushruta Samhita vol. I English translation by Prof. K. R. Srikantha Murty, published by Chaukhambha Orientalia Varanasi, 2014.pag. no.472

5. Astangahridaya (vagbhata) - vidyotani Hindi Commentary by kavirajatridevgupt, viadyayadunandana upadhyaya, Published by Chaukhamba Bharti Academy, Gokul Bhawan, Gopal Mandi Lane, Varanasi, 2011. Page No. 12

6. Astangahridaya (vagbhata) - vidyotani Hindi Commentary by kavirajatridevgupt, viadyayadunandana upadhyaya, Published by Chaukhamba Bharti Academy, Gokul Bhawan, Gopal Mandi Lane, Varanasi, 2011. Page No. 216

7. Sushrutasamhita (sushurta) part 1ayurvedtatvasandipikahindi commentary by ambika data shastri, pranjivanmaanikchand Mehta, Published by Chaukhamba Bharti Academy, Gokul Bhawan, Gopal Mandi Lane, Varanasi, 2010. Page No. 43chikitsa sthan

8. Charaka Samhita (Agnivesh) Part 2- charakachandrika Hindi Commentary by brhmanandtripathii, prabhakarjanardan deshpande, Published by Chaukhamba Bharti Academy, Gokul Bhawan, Gopal Mandi Lane, Varanasi, 2009. Page No. 953

9. Vagbhata, AstangaHridayam, NidanaSthana, Vatavyadhinidanam, 15/54, Arundutta's Commentary, Pt. Hari Sadashiva Shastri Paradakar Bhisgacharya, editor. Reprint ed. 2010. 535.

10. Baily and loves, short practice of surgery; 24th edition, 2004; pno 569.

11. Charaka Samhita (Agnivesh) Part 2- charaka chandrika Hindi Commentary by brhmanand tripathii, prabhakarjanardan deshpande, Published by Chaukhamba Bharti Academy, Gokul Bhawan, Gopal Mandi Lane, Varanasi, 2009. Page No. 286- 287-288

12. Sushruta Samhita vol. I English translation by Prof. K. R. Srikantha Murty, published by Chaukhambha Orientalia Varanasi, 2014.pag. no.472.

13. Astangahridaya (vagbhata) - vidyotani Hindi Commentary by kavirajatridevgupt, viadyayadunandana upadhyaya, Published by Chaukhamba Bharti Academy, Gokul Bhawan, Gopal Mandi Lane, Varanasi, 2011. Page No. 216
14. Yogaratnakara, Vidyotini Hindi Commentary, Vaidya Lakshmipati Shastri, Chaukhambha Prakashana, Varanasi, Reprint edition. 2010. 544.

15. Charaka Samhita (Agnivesh) vol. V, English translation by ram karansharmavaidyabhagwan dash, Published by Chaukhambakrishandas Academy, Gopal Mandir Lane, Varanasi, 2015. Page No. 35

\section{Source of Support: Nil \\ Conflict of Interest: None Declared}

How to cite this URL: C.S. Tanmane et al: A Clinical Review Of Tila Tail Matra Basti In The Management Of Gridhrasi W.S.R To Sciatica. International Ayurvedic Medical Journal \{online\} 2021 \{cited July 2021\} Available from: http://www.iamj.in/posts/images/upload/1597_1602.pdf 